\title{
First Record of Carapus acus (Osteichthyes: Carapidae) in the Gulf of Gabès (southern Tunisia, central Mediterranean Sea)
}

\author{
Samira Enajjar* and Mohamed Nejemeddine Bradai
}

\begin{abstract}
Background: One specimen of Carapus acus was captured in the Gulf of Gabès (southern Tunisia, central Mediterranean Sea), during an experimental bottom trawl survey in the frame of the monitoring of benthic fish stocks of the Tunisian coast. This represents the first record of the pearl fish in the area and a proof of the occurrence of this species in Tunisian coast.

Results: The pearl fish caught measured 136.1 millimeters and it weighed $2.838 \mathrm{gram}$. It has been captured at the following coordinate $34^{\circ} 39^{\prime} 629^{\prime \prime} \mathrm{N} ; 12^{\circ} 45^{\prime} 795^{\prime \prime} \mathrm{E}$ by 100 meters depth. Many Echinoderms were landed during this hauls but any Holoturoidea were observed.

Conclusions: Carapus acus occurs in Tunisian water but others studies are necessary to confirm its abundance, the commensal or parasitic status usually attributed to the carapidae and to determine the host of this species in the Gulf of Gabès.
\end{abstract}

Keywords: Carapus acus, Tunisian coast, Capture confirmation

\section{Background}

The pearl fish, Carapus acus occurred throughout the Mediterranean Sea, mainly in the western basin (Italy, Spain, France, Sardinia and the Balearic Island) and the west coast of North Africa (Nielsen et al. 1999). It occur also in the Adriatic and Aegean Seas. The species has a temperate affinity. Adults are typically commensally in the sea cucumbers: Holothuria stellati, Stichopus regalis and Holothuria tubulosa, which it enters tail or head first (Kloss and Pfeiffer 2000; Eeckhaut et al. 2004). The species was recorded for the first time in Tunisia at 13 miles from the shore of "Kélibia" during the "ORVET" fishing campaign by Pruvot (1921). The author mentions the species under a synonymous names "Fierasfer acus". Lubet and Azzouz (1969) reported the pearl fish for the second time in the Gulf of Tunis under the name of "Fierasfer imberbis".

* Correspondence: enajjarsamira@yahoo.fr

Institut National des sciences et technologies de la mer (centre de Sfax), BP 1035- 3018, Sfax, Tunisia

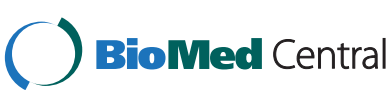

In this study, we record for the first time the pearl fish Carapus acus in the Gulf of Gabès (southern Tunisia) and confirm the occurrence of this species in Tunisian coasts.

\section{Methods}

One specimen of "Carapus acus" was caught on 9 May 2014 between $8 \mathrm{~h} 40 \mathrm{~min}$ and $9 \mathrm{~h} 41 \mathrm{~min}$ a.m. in the Gulf of Gabès $\left(34^{\circ} 39^{\prime} 629^{\prime \prime} \mathrm{N} ; 1^{\circ} 45^{\prime} 795^{\prime \prime} \mathrm{E}\right)$. The capture was occurred by $100 \mathrm{~m}$ depth onboard of the scientific vessel of the National Institute of Sciences and Technologies of the Sea during an experimental bottom trawl survey. The surface temperature was $18^{\circ} \mathrm{C}$.

The fish was brought to the laboratory where it was identified, photographed, measured and weighted. The fish was identified especially using the description given by Trott and Olney (1986).

\section{Results}

The fish was identified as carapus acus (Fig. 1). The measures of the pearl fish are summarized in the Table 1, it weighed 2.838g. Carapus acus is an Eel-like moderate to shallow body depth. It is typically translucent with 


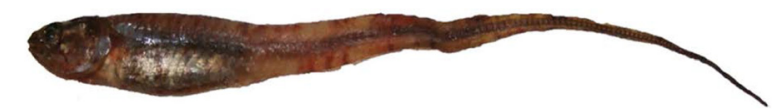

Fig. 1 Carapus acus of the Gulf of Gabès (southern Tunisia). $\mathrm{TL}=136.1 \mathrm{~mm}$

iridescent spots on head and thoracic region. Anal rays are longer than opposite dorsal rays. Anus is anterior to pectoral fin base. The common size is $200 \mathrm{~mm}$ TL.

The species is deposed in the collection of the $\mathrm{Na}$ tional Institute of Sea Sciences and Technologies catalogue at Centre of Sfax under the no. CARAP001.

Many Echinoderms were landed with the pearl fish during the hauls as Echinaster sepositusmany, Astropecten sp., Antedon mediterranea but no Holothuroidea were caught.

\section{Discussion}

The pearl fish was recorded in Tunisian water twice. For the first time in Tunisia by Pruvot (1921) during l'ORVET campaign in the East of kélibia. The specimens was caught by a trawl on a muddy bottom at depth between 107 and $113 \mathrm{~m}$. the second specimens was signaled by Lubet and Azzouz (1969) during an experimental trawling study. It was caught in the circalittoral area of the Gulf of Tunis at a depth ranged between 100 and $200 \mathrm{~m}$ on a detritic fine bottom. In the Gulf of Gabès the species was reported at about $100 \mathrm{~m}$ of depth during an experimental trawling campaign on muddy sandy bottom (Fig. 2). This capture can be considered as the first one in the area. In fact, since 2000 an yearly experimental survey was carried in the area (Hannibal survey). The same hauls were conducted in the same conditions (date, direction, gear...). The species was never being recorded although the commercial portion and the discard part were carefully examined.

The pearl fish live in association with several species of sea cucumbers. This relation is one of the most intimate associations between a vertebrate and an invertebrate host. Carapus acus spend their quiescent hours within the bodies of echinoderms.

Its occurrence in hosts is largely dependent on host availability and its distribution from potential larval areas. In southeastern Spain coast, Stichopus regalis was the only host detected for Carapus acus among six sea cucumber species studied: Holothuria poli, Holothuria mammata, Holothuria tubulosa, Holothuria sanctori, Holothuria arguinensis and Parastichopus regalis (González-Wangüemert et al. 2014). While, Trott (1981), reveal that if the pearl fish Carapus acus have the choice to pick their host they select only $H$. tubulosa.

It use the sea cucumbers as a protection habitat from predation only or also as a source of food, and to develop into its adult stage of life (Kloss and Pfeiffer 2000).

Parmentier and Das (2004), mentioned that the species leave their host holothurians essentially at night, when they presumably feed. The pearl fish of the Gulf of Gabès was captured in the early morning, sea cucumber weren't fished during this experimental trawling hauls. While, 11 Holothuriidae were inventoried in Tunisia water, among them, three species are common in the Gulf of Gabès water: Holothuria forskali, Holoturia tubulosa and Stichopus regalis (Ben Mustapha et al. 1999). After the discovery of the pearl fish, the Holothuroidea observed in discard portion were dissected and examined, no pearl fish were detected.

\section{Conclusion}

The pearl fish Carapus acus is noted for their unusual behaviors and have attracted the attention of natural historians, ichthyologists and physiologists. These slender fish, usually less than $25 \mathrm{~cm}$ TL live in warm Sea. It was captured in Tunisian coast during tree time (northern and southern Tunisian coast) at depth exceed $100 \mathrm{~m}$. The species live in association with several

Table 1 Measurements for the Carapus acus specimen caught in the Gulf of Gabès (southern Tunisia)

\begin{tabular}{lcc}
\hline Measurements & $(\mathrm{mm})$ & $\%(\mathrm{TL})$ \\
\hline Total Length (TL) & 136.1 & - \\
Body depth (BD) & 5.4 & 3.96 \\
Head length (HL) & 16.1 & 3.4 \\
Eye diameter (ED) & 3.3 & 11.83 \\
Pre-orbital length (PoL) & 17.7 & 2.49 \\
Pre-pectoral Length (PpL) & 21.6 & 2.42 \\
Pre-dorsal length (PdL) & 19.1 & 13.00 \\
Pre-anal length (PaL) & & 15.87 \\
\hline
\end{tabular}




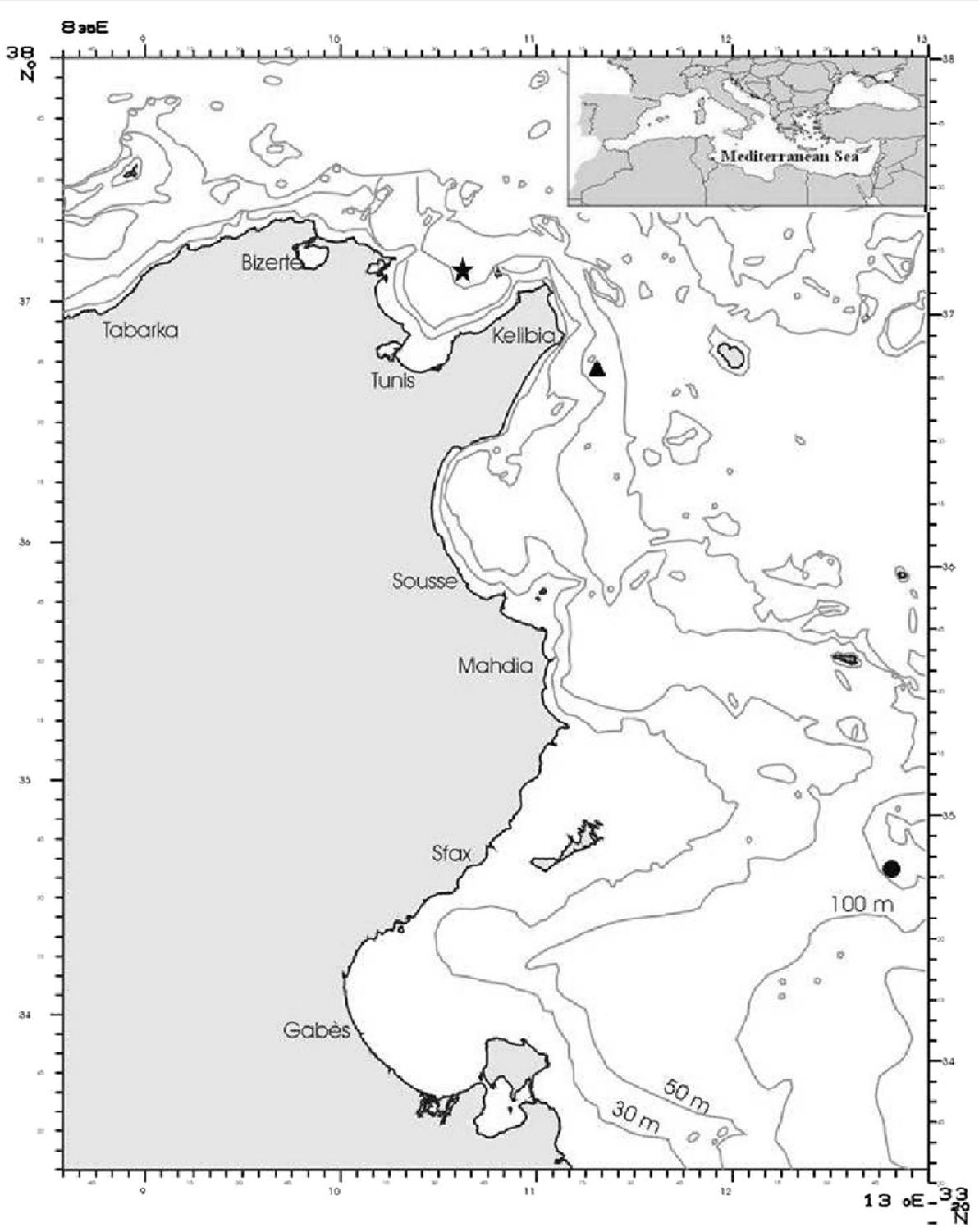

Fig. 2 Sampling sites of Carapus acus. $\bullet$ Present study; $\star$ Pruvot (1921);

Lubet and Azzouz (1969)

species of sea cucumbers and starfish. The signage of the species in the area makes questions about their abundance, its geographical distribution and the nature of these hosts. Many investigations are necessary in order to answers to these topics.

\section{Competing interests}

The authors declare that they have no competing interests.

\section{Authors' contributions}

ES: Conceive of the study and drafted the manuscript. BMN: Participated in the design, coordination and helped to draft the manuscript. All authors have read and approved the final manuscript.

\section{Acknowledgements}

The authors wish to thank Mr. Hentati Zied superior technician and Ben Jarray Fekher principal Engineer in the National Institute of Science and
Technology of the sea (center of Sfax) for providing this specimen. We also acknowledge anonymous referees for providing useful suggestions that significantly improved our manuscript.

Received: 11 February 2016 Accepted: 23 February 2016

Published online: 12 April 2016

\section{References}

Ben Mustapha K, Hattour A, Mhetli M, El Abed A, Tritar B. Etat de la bionomie benthique des étages infra et circalittoral du golfe de Gabès. Bull Inst Océanogr Pêche, Salammbô. 1999;26:5-48.

Eeckhaut I, Parmentier E, Becker P, Da Silva SG, Jangoux M. Parasites and biotic diseases in field and cultivated sea cucumbers. In: Lovatelli A, Conand C, Purcell S, Uthicke S, Hamel JF, Mercier A, editors. Sea cucumber aquaculture and management. Rome : FAO fisheries technical paper 463; 2004. p. 311-326. González-Wangüemert M, Maggi C, Valente S, Martínez-Garrido J, Nuno VR. Parastichopus regalis: The main host of Carapus acus in temperate waters of the Mediterranean Sea and northeastern Atlantic. Beche-de-mer Information Bulletin. 2014;34:38-42. 
Nielsen JG, Cohen DM, Markle DF, Robins CR. An annotated and illustrated catalogue of pearlfishes, cusk-eels, brotulas and other ophidiiform fishes known to date. FAO species catalogue $\mathrm{N}^{\circ}$. 125. Rome: FAO; 1999. 18:178. Kloss K, Pfeiffer W. Zur biologie des « eingeweidefisches » C. acus (Brunnich, 1768) (Carapidae, Teleostei), mit hinweisen auf eine nich-parasitische ernähung. Rev Suisse zool. 2000;107:335-49.

Lubet P, Azzouz A. Etude des fonds chalutables du golfe de Tunis. Bull Inst Océanogr Pêche, Salammbô. 1969;1:87-111.

Parmentier E, Das K. Commensal vs. parasitic relationship between Carapini fish and their hosts: some further insight through $\delta^{13} \mathrm{C}$ and $\delta^{15} \mathrm{~N}$ measurements. J Exp Mar Biol Ecol. 2004;3:47-58.

Pruvot G. Rapport sur la campagne de pêche de l'Orvet dans les eaux tunisiennes. Notes and Mémoire Office Scientifique et Technique des Pêches Maritimes. 1921;8:12.

Trott L. A general review of the pearlfishes (Pisces, Carapidae). Bull Mar Sci. 1981; 31:623-9.

Trott LB, Olney E. Carapidae. In: Whitehead PJP, Bauchot ML, Hureau JC, Nielsen $J \mathrm{E}$, Tortonese $\mathrm{E}$, editors. Fishes of the north-eastern Atlantic and the Mediterranean. Paris: Unesco; 1986. p. 858-64.

\section{Submit your next manuscript to BioMed Central} and we will help you at every step:

- We accept pre-submission inquiries

- Our selector tool helps you to find the most relevant journal

- We provide round the clock customer support

- Convenient online submission

- Thorough peer review

- Inclusion in PubMed and all major indexing services

- Maximum visibility for your research

Submit your manuscript at www.biomedcentral.com/submit 